Article - Human and Animal Health

\title{
Immunogenicity of Escherichia coli Expressing Streptococcus equi subsp. equi Recombinant SeM
}

\author{
Matheus Costa da Rosa ${ }^{1}$ \\ https://orcid.org/0000-0002-0862-9458
}

Neida Lucia Conrad ${ }^{1}$

https://orcid.org/0000-0001-7573-0794

\section{Carina Martins Moraes ${ }^{2}$}

https://orcid.org/0000-0002-7111-8159

\author{
Leandro do Monte Ribas ${ }^{3}$ \\ https://orcid.org/0000-0001-7676-5673
}

Carlos Eduardo Wayne Nogueira ${ }^{4}$

https://orcid.org/0000-0002-8555-7953

\author{
Fábio Pereira Leivas Leite ${ }^{1 *}$ \\ https://orcid.org/0000-0003-0941-7286
}

${ }^{1}$ Federal University of Pelotas (UFPel), Biotechnology, Pelotas, Rio Grande Sul, Brazil; ${ }^{2}$ Federal University of Pará (UFPA), Institute of Veterinary Medicine, Castanhal, Pará, Brazil; 3University of Caxias do Sul (UCS), Caxias do Sul, Rio Grande do Sul; Brazil; 4 Federal University of Pelotas (UFPel), Faculty of Veterinary Medicine, Pelotas, Rio Grande do Sul, Brazil.

Editor-in-Chief: Alexandre Rasi Aoki

Associate Editor: Cheila Roberta Lehnen

Received: 2020.11.16; Accepted: 2021.06.07.

*Correspondence: fleivasleite@gmail.com; fabio_leite@ufpel.edu.br; Tel.: +55 53991276663 (F.P.L.L.).

\section{HIGHLIGHTS}

- E. coli BL21 as a suitable expression and delivery vaccine system;

- $\quad$ rSeM protein protect mice against $S$. equi infection;

- E. coli cells enhance the immune response against $S$. equi;

- rSeM protein, purified or not, presented immunogenicity in horses.

Abstract: The Equine Strangles, caused by Streptococcus equi subs. equi, is a contagious disease, causing high rates of morbidity been responsible for important economic losses. The M protein synthesized by $S$. equi plays an important role in the pathogenesis and is a promising candidate for a vaccine antigen. The innate immune system is responsible for the first immune response against microorganisms, this response is mediated by receptors that detect PAMPs and their activation trigger crucial modulation of the adaptative immune response. This work describes the immune response of $S$. equi subs. equi. recombinant SeM protein, using Escherichia coli BL21 (DE3) as an expression and delivery vaccine system. To characterize and to determine the vaccine efficacy, mice were vaccinated as followed: 1 . Recombinant $E$. coli expressing rSeM protein; 2. The same recombinant E. coli, inactivated adsorbed in Alumen; 3. Purified rSeM protein adsorbed in Alumen; 4. Inactivated S. equi whole cells adsorbed in Alumen; 5. Control group. All vaccinated mice developed protective response against $S$. equi infection, however the groups that received the $E$. coli expressing $\mathrm{rSeM}$ presented significant higher $\mathrm{lgG}$ level than other vaccinated groups. The recombinant $E$. coli delivery vaccine system also induced a highest IgG response than inactivated $S$. equi or purified rSeM vaccines in horses. This study evidence that the recombinant $E$. coli, live or inactivated, enhanced the humoral response, reaching significant higher antibodies levels than those 
obtained in the vaccination with the bacterin or purified antigen, showing the feasibility of producing lowcost vaccines against strangles.

Keywords: Streptococcus equi; SeM protein; PAMPs; recombinant E. coli.

\section{INTRODUCTION}

Bacterial agents have been associated with respiratory problems in equines, among these, one of the most important is the streptococci genre, that is associated with upper tract diseases (Streptococcus equi subsp. equi and $S$. equi subsp. zooepidemicus) [1]. Streptococcus equi infection, also named "Strangles", is characterized by an increase in the volume of lymphonodes in the throat, purulent nasal discharge, cough and fever, causing high rates of morbidity and possibly lethality [2]. Strangles affects horses worldwide, is highly prevalent and contagious, which makes it responsible for several economic losses and an obstacle to the equine sector growth [3].

The $S$. equi cell wall M-like protein (SeM) is responsible for the antiphagocytic capacity and to grip at the host cell, been one of the several main virulence factors of this bacteria. SeM is a major determinant for protection against $S$. equi and plays an important role in horses that recover from the infection $[1,4]$. Strangles vaccines have different formulations and routes of administration, including bacterins and subunit vaccines with SeM and other virulence factors [1,5]. However, vaccines targeting SeM induce only strain specific immunity $[6,7]$. The host protection mechanism for SeM is not yet fully understood and strategies to prevent the spread of this infection still need to be developed. Recent studies have been directed to develop a vaccine that can stimulate the innate and adaptive immunity [8].

The use of $E$. coli prokaryotic system to express recombinant proteins has been widely used in vaccine production [9]. The PAMP's present on microorganisms, as E. coli, enhance the response against vaccine epitopes [10] due to LPS induction of TLR-4 signaling cascade, that activates the nuclear transcription factor NF-kB, resulting in production of pro- inflammatory (TNF- $\alpha$ ) cytokines and interleukins (IL-1, and IL$8)$, giving the modulation of immune responses [11,12].

The objective of this study was to evaluate the immune response of $S$. equi subs. equi. recombinant SeM protein, using E. coli BL21 (DE3) as an expression and delivery vaccine system.

\section{MATERIAL AND METHODS}

\section{Antigen production}

Streptococcus equi subsp. equi (ATCC 9528) was used for the bacterin production. The bacteria were grown in Brain Heart Infusion (BHI, Difco, USA) and incubated under shaking at $37^{\circ} \mathrm{C}$ overnight. The cultures were then centrifuged $(3,000 \times g, 10 \mathrm{~min})$, the pellets suspended in sterile saline buffer and viable bacterial cells was determined by the standard plate count method.

To express the recombinant SeM protein ( $\mathrm{rSeM}$ ) the plasmid containing the SeM protein gene sequence ( $\mathrm{pAE} / \mathrm{SeM}$ ) was transformed into E. coli BL21 (DE3) cells. The rSeM protein expression and recovery was performed as previously described [13]. The rSeM protein expression was evaluated by SDSPAGE on a $12 \%$ separating gel in an electrophoresis system (Bio-Rad, Hercules, California, USA). The expressed protein was purified by affinity chromatography using both HisTrap ${ }^{\mathrm{TM}}$ HP columns pre-packed with pre-charged Ni Sepharose ${ }^{\mathrm{TM}}$ (GE Healthcare,). The purified rSeM fraction was analyzed by Western blot using a monoclonal anti-histidine antibody (Sigma Aldrich). The concentration of the purified protein was determined using the commercial BCA Protein Assay kit (GE Healthcare). The recombinant SeM used in live and inactivated $E$. coli vaccine was quantified by $12 \%$ SDS PAGE using a BSA curve and analyzed in the TotalLab Quant software.

\section{Ethical Parameters}

All mice were maintained and handled at the animal care facility from the Universidade Federal de Pelotas (UFPel), Brazil, and were housed in autoclaved cages (Alesco, Brazil) with no food or water restrictions. All procedures were performed in accordance with the Brazilian Committee for animal care and use (COBEA) guidelines and were approved by the UFPel Ethics Committee for animal research 
(project number 2354). Horses were maintained and handled at the Centro de Ensino e Experimentação em Equinocultura da Palma (CEEEP) - Universidade Federal de Pelotas (UFPel) Capão do Leão- RS. Brazil, and were housed in horses stalls $\left(3 \times 4 \mathrm{~m}^{2}\right)$ with no food or water restrictions. All procedures carried out in this study were approved by the Ethics Committee on Animal research at the Universidade Federal de Pelotas (CEEA-UFPel) under protocol 2354.

\section{Vaccination and challenge}

To evaluate different vaccine formulation 40 Balb/c female mice, 6-8 weeks old, were divided in five groups, with eight animals each. The animals in groups 1-2 were vaccinated with recombinant strain $E$. coli BL21 (DE3) that was previously cloned to express the protein of interest, recombinant SeM protein (rSeM). In group 1 mice received $2 \times 10^{5} \mathrm{CFU} / 100 \mu \mathrm{l}$ of recombinant $E$. coli BL21 (DE3) expressing the rSeM ( 25 $\mu \mathrm{g}$ rSeM protein), the group 2 received the same recombinant E.coli but inactivated $(0.1 \%$ formaldehyde $)$ plus $10 \%$ of Aluminum Hydroxide $\left(\mathrm{Al}(\mathrm{OH})_{3}\right)$ (Sigma-Aldrich) as adjuvant. Group 3 was vaccinated with the $\mathrm{rSeM}(25 \mu \mathrm{g}$ rSeM protein) purified protein plus Aluminum Hydroxide (10\%) as adjuvant. The group 4 received a bacterin, composed by $S$. equi subsp. equi suspension containing $1.2 \times 10^{8} \mathrm{CFU} / \mathrm{ml}$, inactivated with formaldehyde $(0.1 \%)$ and adsorbed in Aluminum Hydroxide (10\%). Animals belonging to group 5, used as control, were inoculated with phosphate buffer (PBS) plus Aluminum Hydroxide (10\%). All mice were vaccinated intramuscularly with two doses of $200 \mu \mathrm{L}$ each on days 0 and 21 of the experiment. Blood samples were collected on days $0,7,14,21,28$ and 42 through submandibular puncture. The sera were obtained by blood centrifugation $(3,000 \times g$ for $5 \mathrm{~min})$ and stored at $-20^{\circ} \mathrm{C}$ for further analysis.

To evaluate the vaccine efficacy vaccinated mice were challenged, on day 42 , with a lethal dose of an isolate of $S$. equi subs. equi, previously characterized [14]. The lethal dose of $S$. equi was determined by Letal Dose $50\left(L_{50}\right)$ assay. Groups of not vaccinated mice were intraperitoneally inoculated with $10^{1}, 10^{2}$ or $10^{3} \mathrm{CFU}$ of $S$. equi $(n=5)$. Animals that reach endpoint criteria were euthanized by deepening anesthesia with inhaled anesthetic agent, isofluorane.

After the vaccine evaluation in mice, was performed an experiment to access the horse's immunogenicity. In group 1 horses were vaccinated with $2 \times 10^{8}$ CFU of recombinant $E$. coli BL21 (DE3) expressing the $\mathrm{rSeM}(\sim 300 \mu \mathrm{g}$ rSeM protein), the group 2 was immunized with the rSeM (300 $\mu \mathrm{g}$ rSeM protein) purified protein plus Aluminum Hydroxide (10\%) as adjuvant. The group 3 received a bacterin, composed by $S$. equi subsp. equi suspension containing $\sim 4 \times 10^{8} \mathrm{CFU} / \mathrm{ml}$, inactivated with formaldehyde $(0.1 \%)$ and adsorbed in Aluminum Hydroxide (10\%). The control group (group 4), was inoculated with phosphate buffer (PBS) plus Aluminum Hydroxide (10\%). All groups contained 5 horses and were vaccinated intramuscularly with a single dose of $2 \mathrm{ml}$ on day 0 . Jugular vein puncture was done to collect blood samples, into vacuum blood collection tubes (Vacutainer®) on days 0,14 and 28.

\section{Antibodies evaluation}

Humoral immune response was accessed by indirect ELISA. Plates (Polysorp, Nunc) were coated with whole inactivated $S$. equi subs. equi cells $\left(10^{8} \mathrm{UFC} /\right.$ well) diluted in carbonate bicarbonate buffer, $\mathrm{pH} 9.6$, overnight at $4^{\circ} \mathrm{C}$. The plates were washed three times with PBS plus $0.5 \%$ Tween 20 (PBS- T). Pool serum samples were diluted 1:100 in PBS and added in triplicate, $100 \mu \mathrm{l} /$ well and incubated for $90 \mathrm{~min}$ at $37^{\circ} \mathrm{C}$. After washing the plates with PBS-T, the secondary antibody anti-mouse IgG HRP-conjugated (Sigma, USA) was added, diluted 1:5000. Plates were again incubated for $90 \mathrm{~min}$ at $37^{\circ} \mathrm{C}$. Finally, were added 100 $\mu \mathrm{l}$ of developing solution (10 mg ortho-phenylenodiamine (OPD, Sigma-Aldrich) in $10 \mathrm{ml}$ of $0.1 \mathrm{M}$ phosphate citrate buffer and $10 \mu \mathrm{l}$ of $30 \% \mathrm{H}_{2} \mathrm{O}_{2}$ ) and incubated for $15 \mathrm{~min}$ at room temperature in the dark. Stop solution (sulfuric acid 3\%) was added and the optical density was read at $492 \mathrm{~nm}$ in an ELISA reader (MR 700 Dynatech Labs). For the IgG isotype evaluation, pooled serum from days 0, 7, 14, 21, 28 and 42 of each group was diluted 1:2000 and ELISA was performed in triplicate according to the instructions of the isotyping kit from Sigma-Aldrich for lgG1 and IgG2a detection. The results represent the mean absorbance obtained in the analysis of the samples in triplicate.

The evaluation of the immune response of vaccinated horses followed the protocol described for analysis of mice sera, with the modification of the secondary antibody and the use of anti-horse IgG HRPconjugated (Sigma, USA). 


\section{Statistical analysis}

The data were analyzed using GraphPad Prism version 7 (USA). Analysis of differences in antibody titers between treatment groups was performed on $\log _{10}$ transformed titer data. The results were subjected to analysis of variance (two-way ANOVA) followed by Tukey's Multiple Comparisons.

\section{RESULTS}

\section{Recombinant E. coli and rSeM protein}

The rSeM protein, was successfully expressed by transformed E. coli BL21 (DE3) strain, showing a band of $58 \mathrm{kDa}$, corresponding to SeM protein, in SDS-PAGE analyzes. The recombinant protein was detected in insoluble form. After purification steps, rSeM was detected by anti-histidine monoclonal antibody in Western blot analysis (Figure 1).

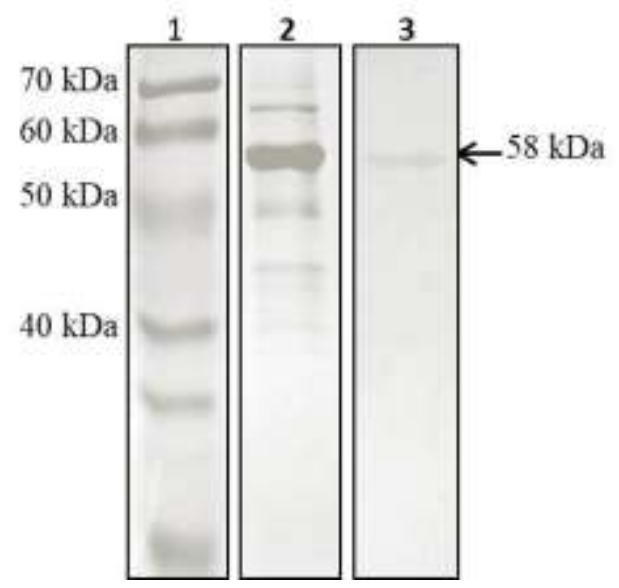

Figure 1. Expression and characterization of recombinant antigens. The proteins expression was analyzed by $12 \%$ SDS-PAGE and Western Blot. 1. Protein ladder; 2. E. coli expressing rSeM protein observed in SDS-PAGE stained with Comassie blue; 3. Purified rSeM protein probed with anti-histidine monoclonal antibody by Western blot.

\section{Immune response}

The humoral immune response against $S$. equi whole cells was accessed by indirect ELISA. Every tested vaccine in this study showed immunogenicity in mice with significant antibodies level with a single dose and increased after the boost dose (Figure 2A). Mice vaccinated with a live or inactivated recombinant $E$. coli presented similar antibodies level between themselves and significant higher ( $4-5$-fold increase) than the group vaccinated with purified $\mathrm{rSeM}$ protein and the $S$. equi bacterin group. The last groups did not show difference between themselves. This kinetics was observed from 7 days after the first vaccination up to the end of the experiment, day $42(\mathrm{P}<0.05)$. The control group (PBS) did not show detectable antibodies (Figure 2A).

Mice IgG response was characterized by the presence of IgG1 and IgG2 isotypes. All vaccinated groups presented lgG1 levels higher than IgG2, especially after $14^{\text {th }}$ day until $28^{\text {th }}$ day (Figure $2 \mathrm{~B}$ and $2 \mathrm{C}$ ). 


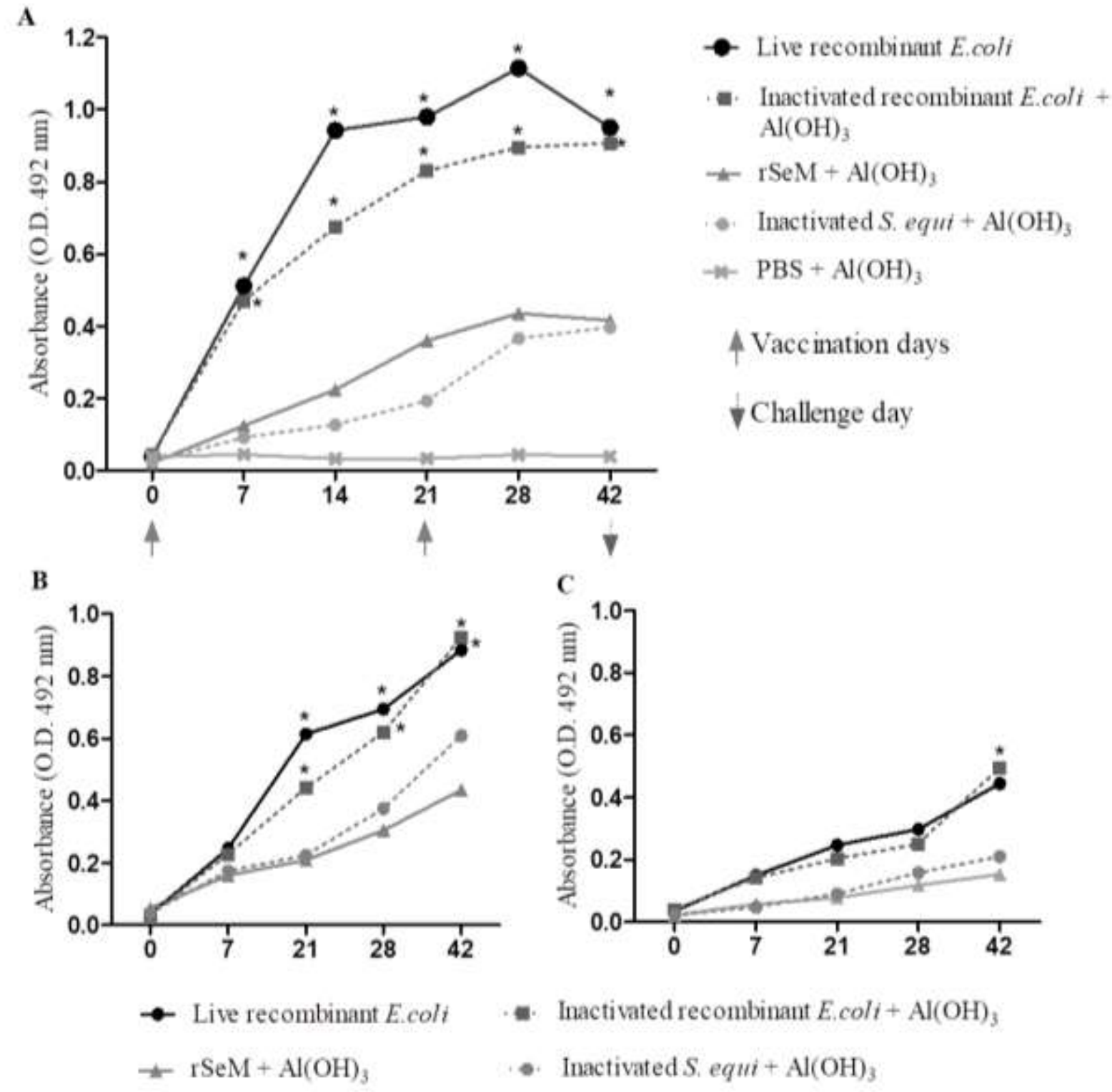

Figure 2. Humoral response. A) Total $\lg G$ kinetics of specific $S$. equi $\lg G$ of the groups vaccinated with the different vaccines; B) IgG1 response; C) IgG2 response. The data represents pool serum mean absorbance values determined by indirect ELISA. All groups presented statistically difference $(P<0.05)$ to the control group (PBS). Asterisk $\left({ }^{*}\right)$ represents difference among the Live and Inactivated recombinant $E$. coli compared with rSeM and Inactivated $S$. equi $(P<0.05)$.

\section{Vaccine efficacy}

To evaluate if the immune response developed by different vaccine formulation was able to induce protection against $S$. equi infection, vaccinated mice were challenged with $10 \times$ Lethal Dose $50\left(\operatorname{LD}_{50}\right)$ of an isolate of $S$. equi subsp. equi equivalent to $10^{2} \mathrm{~S}$. equi CFU. All vaccinated mice survived the lethal infection. No vaccinated group showed endpoint criteria fourth day after the challenge (Figure 3). 


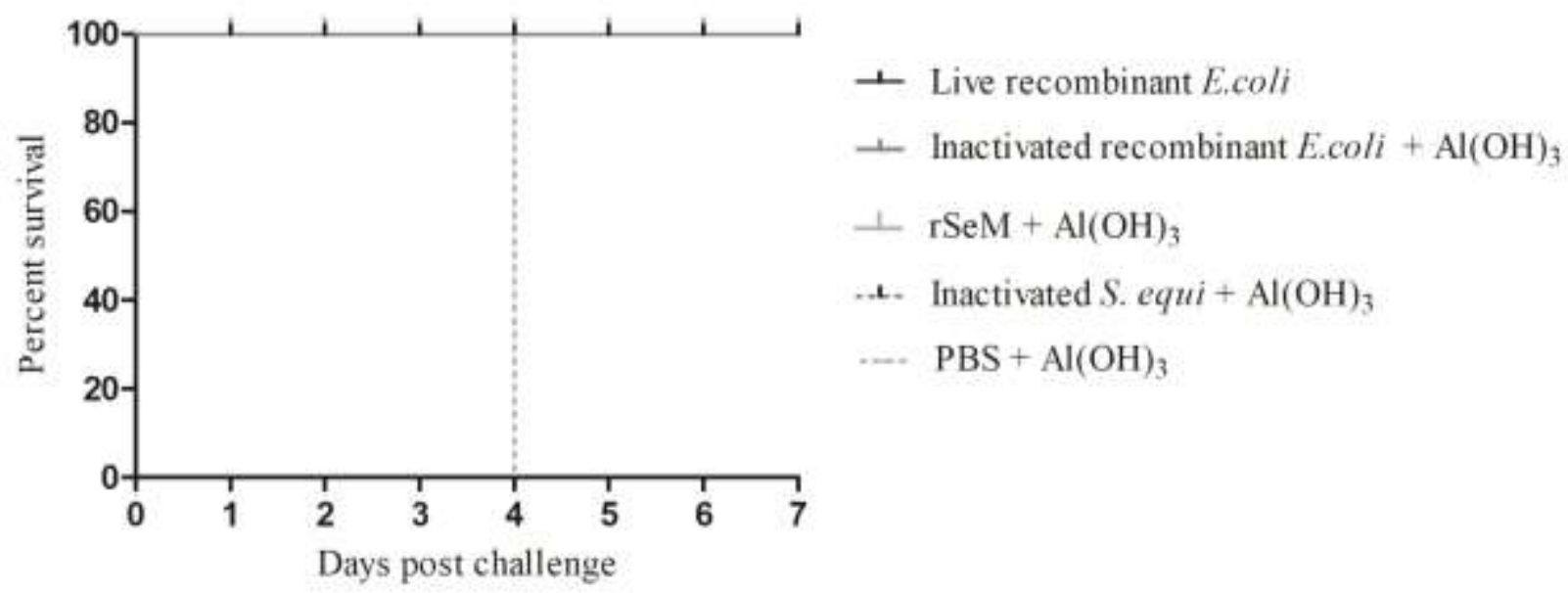

Figure 3. Protection against $S$. equi lethal infection. Vaccinated mice ( 8 animals per group) were submitted to survival challenge by a lethal dose of $S$. equi subsp. equi $\left(10^{2} \mathrm{CFU}\right.$ equivalents to $\left.10 \times L_{50}\right)$.

\section{Horses Vaccine immunogenicity}

Horses vaccinated with a single dose of a live recombinant $E$. coli presented higher lgG level against S. equi whole cells than horses vaccinated with an inactivated S. equi or rSeM (Figure 4).

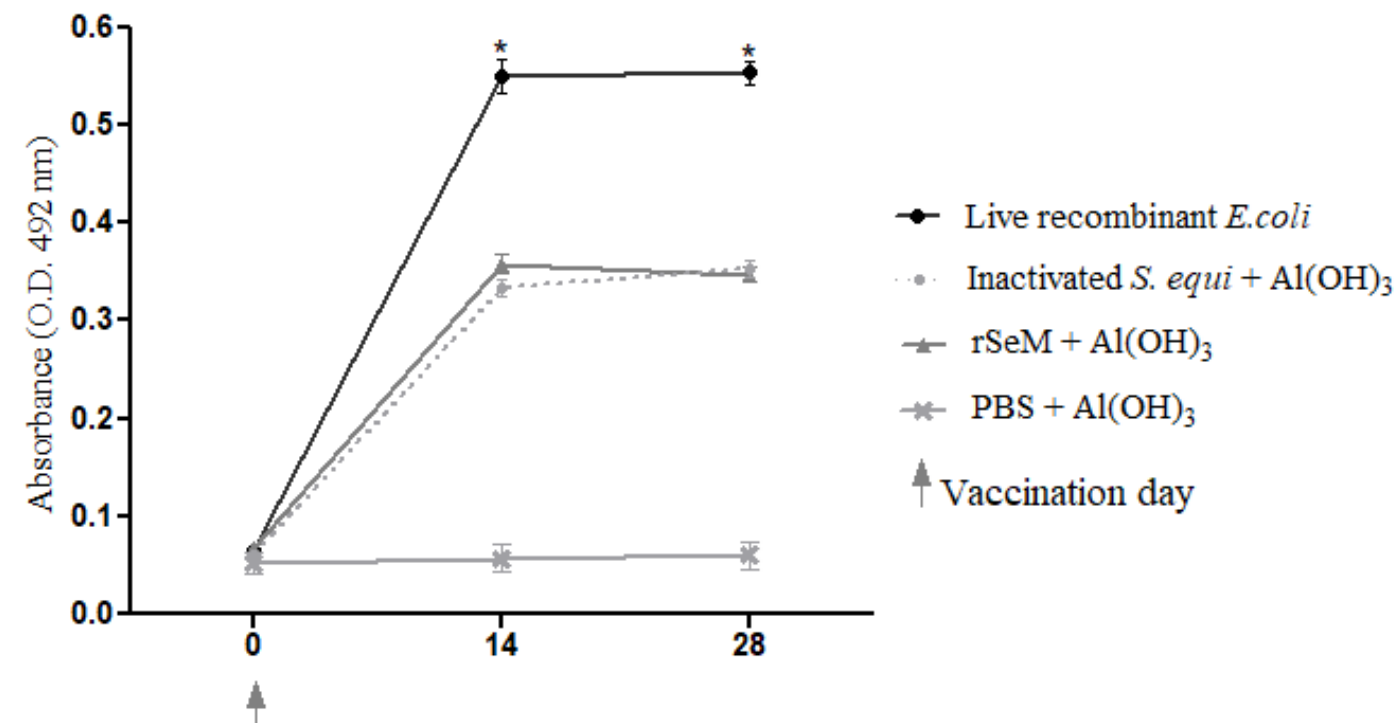

Figure 4. Vaccine immunogenicity in horses. Response against $S$. equi whole cells in horses vaccinated with a live recombinant $E$. coli or $S$. equi bacterin. The data represents the mean absorbance values determined by indirect ELISA from individual serum samples analysis. All groups presented statistically difference $(P<0.05)$ to the control group (PBS). Asterisk $\left({ }^{*}\right)$ represents difference among the Live recombinant $E$. coli compared with $r S e M$ and Inactivated $S$. equi $(\mathrm{P}<0.05)$.

\section{DISCUSSION}

Streptococcus equi is the pathogen responsible for strangles, one of the most common worldwide infections in horses. This is an old problem, that still causes significant economic losses to the sector. Although different vaccines are available, they are not completely harmlessness or effective [15]. In addition to the conventional commercial and autogenous bacterins on the market, live attenuated vaccines are also available for use in specific regions such as U.S., New Zealand and Australia [16]. However, in Europe, live attenuated vaccines have not been approved for use due to cases of reversion in virulence $[15,16]$. The Equilis StrepE $\AA$, another live attenuated vaccine against strangles, had its production discontinued due to inducing short-term immunity [17] and also by presenting problems due to its harm [18].

Vaccines developed with recombinant technologies, such as the use of toxins, subunit proteins and DNA vaccines have been explored $[19,20]$. However, due to problem with low immunogenicity and antigen 
purification costs, the conventional bacterins still play a major role in preventing diseases [21,22]. Wholecell microorganism vaccines are comprised of many antigens, as well as important molecules in immune responses triggering [23]. The innate immune system is responsible for the first immune response against microorganisms, this response is based, in part, by Toll-like receptors (TLR) that detect pathogens and modulate an appropriate protective immune response [11]. These receptors bind specifically to microbial structures called Pathogen Associated Molecular Patterns (PAMPs), these include lipopolysaccharide (LPS), flagellin, lipoproteins, glycolipids and nucleic acids bacterin origin, among others [24]. Studies describing that $E$. coli cell-based system, containing the antigen of interest in experimental vaccines, is capable to prevent other animal diseases [25]. The vaccine composed by the formaldehyde-inactivated recombinant $E$. coli was able to induce neutralizing antibodies against BoNTs $C$ and D in cattle [26]. Also, recombinant $E$. coli vaccines can effectively induce high antibody titers against Clostridium perfringens alpha (CPA) and epsilon (ETX) toxins in rabbits and ruminants [27].

In this study a vaccination strategy that combines the immunogenic properties of the bacterin with the specificity of recombinant subunit vaccines was evaluated. The rSeM protein was expressed in $E$. coli and the bacteria was also used to enhance the immune response. SeM protein was selected because it plays an important role in the pathogenesis of $S$. equi [4,5]. Also, it induces $\lg A$ and $\lg G$ antibodies in infected horses $[27,28]$ demonstrating that it activates the immune system stimulating humoral response. However, vaccines targeting SeM may induce only strain specific immunity because of the polymorphic nature of the SeM gene [6,7]. The host protection mechanism for SeM is not yet fully understood and strategies to prevent the spread of this infection still need to be developed. Since parenteral administration of SeM does not result in a satisfactory mucosal response, most recent studies have been directed at stimulating the innate and adaptive immunity $[8,29]$.

The live recombinant $E$. coli containing rSeM protein and the inactivated recombinant $E$. coli adsorbed in alumen as adjuvant showed similar antibody level against whole $S$. equi cells between themselves. The recombinant $E$. coli vaccines presents higher antibody values $(\mathrm{P}<0.05)$ than the $S$. equi bacterin or purified rSeM vaccines (Figure 2). Thus, one may suggest that the presence of PAMPs in E. coli cells enhances humoral immune response. Bacterins are generally composed of large amount of LPS, the major PAMPs present in E. coli [30]. Studies show that LPS is recognized by TRL-4, inducing the transcription factor NF-kB activation, resulting in the production of pro-inflammatory cytokines and interleukins, modulating antibodies production [31]. It was worth nothing that the live recombinant $E$. coli containing rSeM protein showed higher antibody values in a mouse model as well as in horses. This finding is important by two folds: (i) the formalin inactivation process reduced the rSeM immunogenicity as reported by [25], and (ii) this open a promising vaccine alternative by using non-pathogenic $E$. coli as deliver antigen(s) $[32,33,34,35,36]$ for strangles control.

In the characterization of the IgG response profile was observed that all groups have a predominance of the lgG1 isotype compared to the levels of $\lg G 2$, which, although detectable, have lower levels than $\lg \mathrm{G} 1$ in most of the study points (Figure 2). The presence of IgG1 in the mouse is indicative of a Th2-like response, the most effective against extracellular pathogens, while IgG2a, IgG2b and IgG3 are associated with a Th1 response and protection against intracellular pathogens. Since Streptococcus spp. is regarded as extracellular pathogens, a protective immune response should be based towards proliferation of Th2 cells and the presence of IgG1. The use of alumen as adjuvant in the vaccine polarizes a Th2 response by inhibiting IL-12 from DCs [37,38].

To determine the effectiveness of experimental vaccines using a mouse model, a challenge/protection test was done. S. equi subsp. equi Lethal Dose $50\left(L_{50}\right)$ for Balb/c mice was performed using three groups (5 mice/group) of mice. The mice were intraperitoneal inoculated with $10^{1}, 10^{2}$ or $10^{3} \mathrm{CFU}$ of $S$. equi, and observed for $96 \mathrm{~h}$. The assay evidenced that $10^{1} \mathrm{~S}$. equi CFU concentration was able to cause lethal infection in $50-70 \%$ of infected mice. Therefore, for the challenge/protection assay we used a dose of $10^{2}$ $S$. equi CFU, equivalent to $10 \times \mathrm{LD}_{50}$. The vaccinated mice remained healthy after the challenge, while the control group, reached the endpoint criteria $96 \mathrm{~h}$ after infection (Figure 3).

In our study all vaccinated mice developed a protective response to $S$. equi infection, evidenced by the surviving to the lethal challenge. These results corroborate with studies that show that the presence of antiSeM antibodies can be correlated with protective immunity against infection by $S$. equi [39], since the purified rSeM vaccine also induced protective response. The rSeM protein was expressed in insoluble form, so it was solubilized with urea buffer and then submitted to purification process. All urea was removed before animal's vaccination by slow dialysis to avoid protein precipitation. These steps, necessary to obtain the purified antigen, increase the cost and time for vaccine production. 
The results obtained in the murine infection model revealed that vaccines consisting of $E$. coli expressing rSeM are a promising alternative for the prevention of $S$. equi infection. Live recombinant $E$. coli vaccine demonstrated immunogenicity and harmlessness in horses, which showed specific antibodies after a single dose (Figure 4). The use of unpurified antigen facilitated the vaccine production, since rSeM is expressed in insoluble form, requiring solubilization steps with urea buffer and subsequent dialysis, besides the purification process is costly and laborious.

Therefore, we verified the potential of a vaccine based on $E$. coli expressing rSeM protein against equine strangles. We observed that the recombinant $E$. coli, live or inactivated, enhanced the humoral response, reaching higher antibodies levels than those obtained in the vaccination with the $S$. equi bacterin or purified antigen.

Funding: This work was supported by Coordination for the Improvement of Higher Education Personnel (CAPES) Brazil - Finance Code 001 and National Council of Technological and Scientific Development (CNPq).

Conflicts of Interest: The authors declare no conflict of interest.

\section{REFERENCES}

1. Castillo-Olivares J, Wood J. West Nile virus infection of horses. Vet. Res. 2004 Jul;35(4):467-83. Avaliable from: https://doi.org/10.1051/vetres:2004022

2. Taylor SD, Wilson WD. Streptococcus equi subsp. equi (Strangles) Infection. Clin Tech Equine Pract. 2006;5(3):211-7.

3. Waller AS, Paillot R, Timoney JF. Streptococcus equi: A pathogen restricted to one host. J. Med. Microbiol. 2011 Set 01;60(9):231-40. Avaliable from: https://doi.org/10.1099/jmm.0.028233-0

4. Timoney JF, Artiushin SC, Boschwitz JS. Comparison of the sequences and functions of Streptococcus equi Mlike proteins SeM and SzPSe. Infect Immun. 1997;65(9):3600-5.

5. Flock M, Jacobsson K, Frykberg L, Hirst TR, Franklin A, Guss B, et al. Recombinant Streptococcus equi proteins protect mice in challenge experiments and induce immune response in horses. Infect Immun. 2004;72(6):322836.

6. Timoney JF, Qin A, Muthupalani S, Artiushin S. Vaccine potential of novel surface exposed and secreted proteins of Streptococcus equi. Vaccine. 2007 Feb 26;25(30):5583-90. Avaliable from: https://doi.org/10.1016/j.vaccine.2007.02.040

7. Sheoran AS, Artiushin S, Timoney JF. Erratum: Nasal mucosal immunogenicity for the horse of a SeM peptide of Streptococcus equi genetically coupled to cholera toxin. Vaccine. 2002;20:1653-9.

8. Vicente S, Prego C, Csaba N, Alonso MJ. From single-dose vaccine delivery systems to nanovaccines. J Drug Deliv Sci Technol. 2010;20(4):267-76. DOI:10.1016/S1773-2247(10)50044-3.

9. Flock M, Karlström A, Lannerg J, Guss B, Flock J. Protective effect of vaccination with recombinant proteins from Streptococcus equi subspecies equi in a strangles model in the mouse. Vaccine. 2006 May 8; 24(19):4144-51. DOI: 10.1016/j.vaccine.2006.02.016.

10. Srivastava PK. Immunotherapy of human cancer: Lessons from mice. Nat Immunol. 2000;1(5):363-6. DOI: $10.1038 / 808795$

11. Akira S, Takeda K. Focus on TLR signalling - Toll-Like receptors signalling. Nat Rev Immunol. 2004 Jul; 4(7):499511. DOI: $10.1038 /$ nri1391.

12. Medzhitov R, Preston-Hurlburt P, Janeway CA. A human homologue of the Drosophila toll protein signals activation of adaptive immunity. Nature. 1997 Jul 24;388(6640):394-7. DOI:10.1038/41131.

13. Moraes CM, Conceição FR, Rocha ASR, Santos Júnior AG, Ribas LM, Vargas APC, et al. Cloning, expression and characterization of SeM protein of Streptococcus equi subsp. equi and evaluation of its use as antigen in an indirect ELISA. Arq Bras Med Vet e Zootec. 2014;66(4):1015-22. DOI:10.1590/1678-6034

14. De Moraes CM, Silva MS e., de Vargas APC, Nogueira CEW, Leite FPL, Gil-Turnes C. Immunogenicity and cross reactivity indices of Streptococcus equi subsp. equi strains isolated from cases of Strangles and commercial vaccines. Cienc Rural. 2009;39(5):1459-64. DOI:10.1590/1678-6034

15. Cursons R, Patty O, Steward KF, Waller AS. Strangles in horses can be caused by vaccination with Pinnacle I. N. Vaccine. 2015;33(30):3440-3. DOI:10.1016/j.vaccine.2015.05.009.

16. Ma X, Wang C, Zhang B, Xia L, Su Y. Antibody kinetics and immune pro fi le analysis of a Streptococcus equi DNA vaccine expressing the FljB and SeM fusion protein in murine and equine models. Res Vet Sci. 2019 May 21;125:82-88. DOI:10.1016/j.rvsc.2019.05.014

17. Waller AS, Jolley KA. Getting a grip on strangles: Recent progress towards improved diagnostics and vaccines. Vet J. 2007 May;173(3):492-501. DOI:10.1016/j.tvjl.2006.05.011. 
18. Kemble T, Waller A. Modified live Streptococcus equi (' strangles ') vaccination followed by clinically adverse reactions associated with bacterial replication. Equine Vet J. 2007 May;39(3):284-6. DOI:10.2746/042516407×195961.

19. Robinson C, Frykberg L, Flock M, Guss B, Waller AS, Flock J. Strangvac: A recombinant fusion protein vaccine that protects against strangles, caused by Streptococcus equi. Vaccine. 2018 Mar 7;36(11):1484-1490. DOI:10.1016/j.vaccine.2018.01.030.

20. Boyle AG, Timoney JF, Newton JR, Hines MT, Waller AS, Buchanan BR. Streptococcus equi Infections in Horses: Guidelines for Treatment, Control, and Prevention of Strangles-Revised Consensus Statement. J Vet Intern Med. 2018 Mar; 32(2):633-647. DOI: 10.1111/jvim.15043.

21. Sturbelle RT, Conceição RCS, Da Rosa MC, Roos TB, Dummer L, Leite FPL. The use of quorum sensing to improve vaccine immune response. Vaccine. 2013 Dec 17;32(1):90-5. DOI:10.1016/j.vaccine.2013.10.065

22. Zhang W. Progress and challenges in vaccine development against Enterotoxigenic Escherichia Coli (ETEC)Associated porcine post- weaning diarrhoea (PWD). J Vet Med Res. 2014;1(2):1006.

23. Walker PD. Bacterial vaccines: Old and new, veterinary and medical. Vaccine. 1992;10:977-90.

24. Kawai T, Akira S. TLR signaling. Cell Death Differ. 2006;13:816-825. DOI:10.1038/sj.cdd.4401850

25. Tobias J, Svennerholm AM, Carlin NIA, Lebens M, Holmgren J. Construction of a non-toxigenic Escherichia coli oral vaccine strain expressing large amounts of CS6 and inducing strong intestinal and serum anti-CS6 antibody responses in mice. Vaccine. 2011; 29 (48):8863-9. DOI: 10.1016/j.vaccine.2011.09.096.

26. Moreira C, Ferreira MRA, Finger PF, Magalhães CG, Cunha CEP, Rodrigues RR, et al. Protective efficacy of recombinant bacterin vaccine against botulism in cattle. Vaccine. 2020 Mar 4; 38(11):2519-2526. DOI: 10.1016/j.vaccine.2020.01.089.

27. Ferreira MRA, Motta JF, Azevedo ML, dos Santos LM, Júnior CM, Rodrigues RR, et al. Inactivated recombinant Escherichia coli as a candidate vaccine against Clostridium perfringens alpha toxin in sheep. Anaerobe. 2019 Oct;59:163-166. DOI: 10.1016/j.anaerobe.2019.07.002.

28. Harrington DJ, Sutcliffe IC, Chanter N. The molecular basis of Streptococcus equi infection and disease. Microbes Infect. 2002 Apr;4(4):501-10. DOI: 10.1016/s1286-4579(02)01565-4.

29. Lindahl S, Söderlund R, Frosth S, Pringle J, Båverud V, Aspán A. Tracing outbreaks of Streptococcus equi infection (strangles) in horses using sequence variation in the seM gene and pulsed-field gel electrophoresis. Vet Microbiol. 2011 Nov 21;153(1-2):144-9. DOI: 10.1016/j.vetmic.2011.03.027.

30. Herath S, Fischer DP, Werling D, Williams EJ, Lilly ST, Dobson H, et al. Expression and Function of Toll-Like Receptor 4 in the Endometrial Cells of the Uterus. Endocrinology. 2006 May; 147(1):562-570. DOI:10.1210/en.2005-1113.

31. Takeuchi O, Akira S. Review Pattern Recognition Receptors and Inflammation. Cell. 2010 Mar 19;140(6):805-820. DOI: 10.1016/j.cell.2010.01.022.

32. Liu J, Sun Y, Feng S, Zhu L, Guo X, Qi C. Towards an attenuated enterohemorrhagic Escherichia coli O157:H7 vaccine characterized by a deleted ler gene and containing apathogenic Shiga toxins. Vaccine.2009;27(43):592935. DOI: 10.1016/j.vaccine.2009.07.097.

33. Byrd W, Boedeker EC. Attenuated Escherichia coli strains expressing the colonization factor antigen I (CFA/l) and a detoxified heat-labile enterotoxin (LThK63) enhance clearance of ETEC from the lungs of mice and protect mice from intestinal ETEC colonization and LT-induced fluid accumulation. Vet Immunol Immunopathol. 2013;152(12):57-67. DOI: 10.1016/j.vetimm.2012.10.001.

34. Gupta KV, Radhakrishnan G, Harms J, Splitter G. Invasive Escherichia coli vaccines expressing Brucella melitensis outer membrane proteins 31 or 16 or periplasmic protein BP26 confer protection in mice challenge with B. melitensis. Vaccine.2012;30(27):4017. DOI: 10.1016/j.vaccine.2012.04.036.

35. Turner AK, Beavis JC, Stephens JC, Greenwood J, Gewert C, Thomas N, Deary A, Casula G, Daley A, Kelly P, Randall R, Darsley MJ. Construction and Phase I Clinical Evaluation of the Safety and Immunogenicity of a Candidate Enterotoxigenic Escherichia coli Vaccine Strain Expressing Colonization Factor Antigen CFA/I. Infect Immun. 2005; 74(2): 1062-71. DOI: 10.11128/IAI.74.21062-1071.

36. Zhang J, Shi Z, Kong F, Jex E, Huang Z, Watt JM, Van Kampen KR, Tang DC. Topical Application of Escherichia coli-Vectored Vaccine as a Simple Method for Eliciting Protective Immunity. Infect Immun. 2006; 74(6): 3607-17. DOI: 10.11128/IAI.01836-05.

37. Mori A, Oleszycka E, Sharp FA, Coleman M, Ozasa Y, Singh M, et al. The vaccine adjuvant alum inhibits IL-12 by promoting PI3 kinase signaling while chitosan does not inhibit IL-12 and enhances Th1 and Th17 responses. Eur J Immunol. 2012 Oct;42(10):2709-19. DOI: 10.1002/eji.201242372. 
38. Coffman RL, Sher A, Seder RA. Vaccine Adjuvants: Putting Innate Immunity to Work. Immunity. 2010 Oct 29; 33(4):492-503. DOI:10.1016/j.immuni.2010.10.002

39. Mallicote M. Update on Streptococcus equi subsp equi Infections. Vet Clin North Am Equine Pract. 2015 Apr; 31(1):27-41. DOI: 10.1016/j.cveq.2014.11.003.

(C) (5) 2021 by the authors. Submitted for possible open access publication under the terms and
conditions of the Creative Commons Attribution (CC BY NC) license (https://creativecommons.org/licenses/by-nc/4.0/). 